Jurnal Pena Sains Vol. 6, No. 1, April 2019

p-ISSN: 2407-2311

e-ISSN: 2527-7634

\title{
ADIRAMA: PRODUCTION AND USE OF THE SALT ADDITIVE OF MADURA
}

\author{
Rahmad Fajar Sidik ${ }^{1}$ and Makhfud Efendy ${ }^{2}$ \\ ${ }^{1}$ Program Studi Pendidikan IPA Universitas Trunojoyo Madura \\ Bangkalan, 69162, Indonesia \\ rahmadfajarsidik@gmail.com \\ ${ }^{2}$ Program Studi Ilmu Kelautan Universitas Trunojoyo Madura \\ Bangkalan, 69162, Indonesia \\ makhfud.efendy@trunojoyo.ac.id
}

Accepted: October30, 2018

Published: April 30, 2019

DOI: http://doi.org/10.21107/jps.v6i1.5258

\begin{abstract}
Salt of Madura is a unique product and dominates in the local and regional markets. It is the result of sweat and sweat from local youth in seeking and living life. The process of using salt additives is an idea that arises because naturally the people of Madura have used it, which is adding trusion in terms of facing the water process that it has. The sea water that experiences the process of adding additives has the highest $\mathrm{NaCl}$, ceramics land 96.02\%, LDPE land 95.72\% and soil area 93.81\%. Whereas those who were not treated had lower $\mathrm{NaCl}, 93.94 \%$ ceramics, LDPE $92.65 \%$ and soil $87.78 \%$. And for some treatments for some treatments heavier than others, namely ceramic additives $47.65 \mathrm{Kg}$, additive LDPE $49.15 \mathrm{Kg}$, and additive soil $32.50 \mathrm{Kg}$. While the soil that is not treated is mostly lower in salt, non-additive ceramics $46.75 \mathrm{Kg}$, non-additive LDPE $50.75 \mathrm{Kg}$ and non-additive soil $26.95 \mathrm{Kg}$.
\end{abstract}

Keywords: Salt of Madura, additives, $\mathrm{NaCl}$, ceramic land, LDPE land, soil

\footnotetext{
${ }^{1}$ Corresponding Author
} 


\section{ADIRAMA: Production and Use of The Salt Additive of Madura}

\section{Introduction}

Salt production centers are concentrated in Madura, Java, Sulawesi and NTB. The area of salt land in Java is 10,231 Ha, the area of Madura is 15,347 $\mathrm{Ha}$, while the area managed by PT Garam is only $5,116 \mathrm{Ha}$ (all of which are on the island of Madura in Sumenep 3,163 Ha, Pemekasan $907 \mathrm{Ha}$ and Sampang 1,046 $\mathrm{Ha})$. Other locations are in NTB covering 1,155 hectares, South Sulawesi 2,040 hectares, Sumatra and others 1,885 hectares. Based on the total salting area of $30,658 \mathrm{Ha}$, as many as 25,542 $\mathrm{Ha}$ $(83.31 \%)$ are managed traditionally by the people (Efendy et al., 2011).

The area of salt ponds in Pamekasan district is located in three Subdistricts namely Pademawu, Galis and Tlanakan subdistrict. All areas of the pond are located on the southern coast bordering the waters of the Madura Strait. The area of salt ponds in Pamekasan district reaches 2,096.50 Ha. The largest area of salt ponds is in Pademawu subdistrict, while the narrowest in Tlanakan subdistrict.

Based on the area $(2,096.50 \mathrm{Ha})$ in the field of salt ponds, the land area that only used for salt ponds is $1,868.70 \mathrm{Ha}$ $(89.13 \%)$. The management of salt ponds in Pamekasan district generally divided into two: management by PT Garam and private salt companies and control by individuals known as traditional salt fields. The area of salt farms managed by the company is $980.0 \mathrm{Ha}(52.44 \%)$, while the remaining $47.56 \%(888.70 \mathrm{Ha})$ land for community salt farms. The land of the people's salt ponds is in three subdistricts, namely Galis, Pademawu and Tlanakan. The widest area of community salt ponds is in Galis Subdistrict reaching $353 \mathrm{Ha}$, while Tlanakan Subdistrict is the area with the narrowest community salt pond area of $35 \mathrm{Ha}$. From the size of the farm area of 888.7 hectares, in the regular dry season salt can produce 88-98 thousand tons. The short production period due to high rainfall in the dry season results in a decrease in salt production. The significant decline in traditional salt production in Pamekasan district occurred in the 2010 season. In that year the production of salt produced by community farms was only 225 tons.

The main problem of developing traditional salt managed by the community is 1) traditional production technology and the quality of salt is still low; 2) salt production depends on the season; 3) still traditional land management; 4) availability and quality of infrastructure is still low, thus increasing production costs; 5) low and fluctuating salt prices; and 5) productivity is not optimal. The phenomenon of climate change/climate today is very influential for the survival of the people's salt business. This phenomenon results in increasingly short periods of salt production. In 2010, due to high rainfall throughout the year, most of the people's salt production experienced crop failures. Weather disruption during the production period also resulted in a decline in the quality of salt. It is because most salt production is highly dependent on solar radiation.

The method of making salt from the people is still using total solar evaporation. Productivity and quality of salt produced are still low and generally have a $\mathrm{NaCl}$ level of less than $90 \%$ with a relatively high water content and impurity. The average production level of traditional salt by the community ranges from 50-70 tons/ha/year with different qualities ranging from $\mathrm{K} 1( \pm 20 \%), \mathrm{K} 2( \pm$ $45 \%)$ and $\mathrm{K} 3( \pm 35 \%)$. This condition is very far, compared to the productivity of Australian salt which is capable of 


\section{Sidik and Efendy}

reaching 400 tons/ha/year with consistent quality, almost all of them in $\mathrm{K} 1$.

Improving production technology to enhance the quality of salt and productivity is essential for the development of traditional salt managed by the community. The salt quality improvement is carried out through efforts to increase salt $\mathrm{NaCl}$ levels and consumption salt processing efforts. Increased levels of salt $\mathrm{NaCl}$ can be done by separating the content of calcium and magnesium at the beginning of the production period using salt additives.

\section{Research Method}

This research conducted in Pamekasan district from June to October 2017. Figure 1 is the location of research activities.

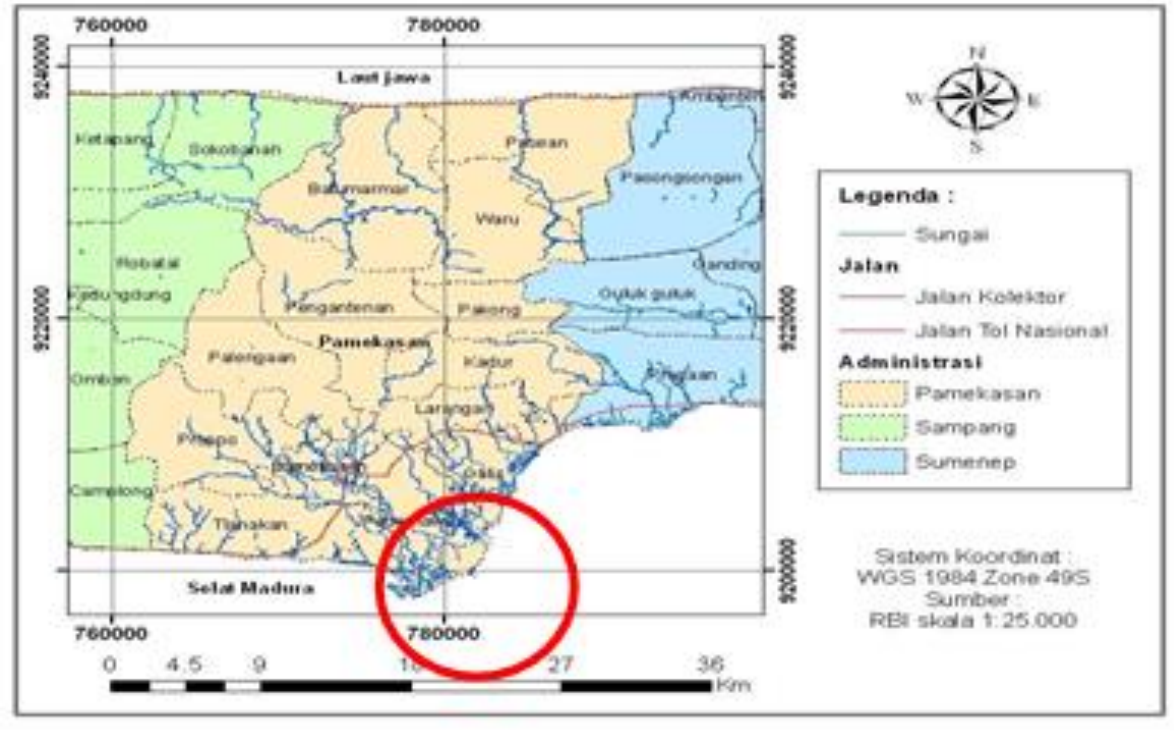

Figure 1. Research Area for Salt Production Demonstration Plots

This research divided into three major activities, namely: 1) Making salt additives; 2) Deposition processes 1 and 2 with the addition of salt additives $A$ and B; and 3) Application to salt ponds. Each activity will be traced to the results as shown in Figure 2.

The first activity begins with the preparation of salt additives, including banana midribs, rocks, and rice husks. These materials burned in the burner furnace with different temperatures and combustion times depending on the material burned. After the combustion process, the next process is to reduce the size by using a flour grinder for limestone, while for the banana midrib and husk only a filtration process is carried out to separate the ash from other impurities. The constituents mixed with different percentages according to the treatment carried out. In the development of ADIRAMA additives, there are two types of formulations namely formulations $\mathrm{A}$ and $\mathrm{B}$.

The additive deposition process carried out twice, namely, deposition 1 using additive formula $\mathrm{A}$ followed by deposition 2 using formula B additives. Furthermore, the application of the resulting water from the deposition process into the crystallization table was by the desired treatment, treatment in this study was 6 treatments. 


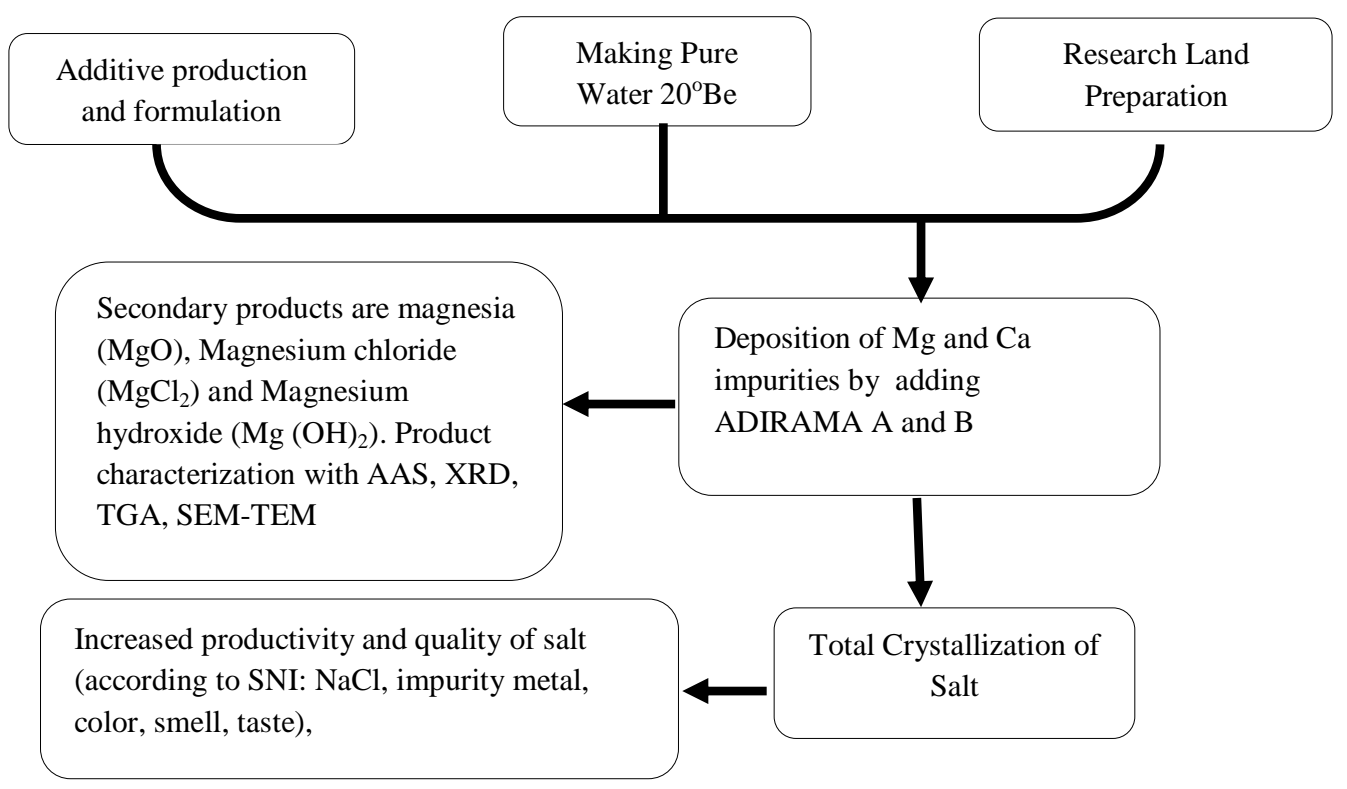

Figure 2. Research Flow

\section{Result and Discussion}

Salt produced by the community is generally without washing, resulting in low quality. Therefore, the salt does not meet salt quality standards for the purchase of national stock. This results in the selling price of salt produced by the people tend to be low. Salt as consumption salt must in some quality standard requirements or criteria including appearance that is clean, white, odorless, low humidity level, and not contaminated by lead and other metal materials. In its development, the standard of consumption salt has been set a reference standard, namely SNI 01-35562000. This SNI compiled about the Indonesian Food Code of 1979.

Salt additives are materials used to accelerate the process of crystallizing high-quality salts. Additives that have been popular in Indonesia are Ramsol (Indramayu). Additives to be used in salt production are known as ADIRAMA formulations.
The types of the composition of the ADIRAMA additive are seaweed activated charcoal, activated rice husk charcoal, rock activated charcoal, and sea shellfish activated charcoal. The composition of the ingredients is chosen based on the content of the activated charcoal. In addition, consideration of the level of availability of raw materials in Pamekasan. The composition of the additives is available in huge quantities and very easily found in the local area.

The results of the application of additives of Phase I ADIRAMA are to determine the speed of increase in Be. The formation of salt flowers and the speed of fall of salt flowers as salt crystals in each treatment, the treatment applied in this application include additives ADIRAMA with various compositions and concentrations (5 different compositions and level of ADIRAMA additives), with and without the addition of RAMSOL additives. 
Salt production from the application I analyzed in the laboratory showed a negative relationship with the water content indicator with $\mathrm{NaCl}$ levels, that is, if the water content were high then the $\mathrm{NaCl}$ level would be relatively low. It can be interpreted that the salt produced from the application 1 classified as tends to be wet with high water content. From laboratory tests, it was seen that salt water content ranged from $8-12 \%$. While the levels of $\mathrm{NaCl} 88-92 \%$. This condition is understandable because the trial was carried out on open land in the rainy season. If the experiment is carried out in the dry season (dry season) it is predicted that the salt produced will increase $\mathrm{NaCl}$ levels more. The potential for increased levels of $\mathrm{NaCl}$ with the use of additives is huge, considering the relatively small impurity content which is below $0.5 \%$.

The results of Application I also show that the five ADIRAMA formulations have a similar effect, namely an increase in the speed of salt flower formation and the speed of salt crystal drop faster than without additives (plot 7) even faster than RAMSOL additives (plot 6 ) at the concentration same. The rate of formation of salt flowers in plots 1 to plot 5 (addition of ADIRAMA additives) is related to additives which consist of elements $\mathrm{O}$ (from $\mathrm{H} 2 \mathrm{O}, \mathrm{SiO} 2, \mathrm{CaO}$, $\mathrm{MgO}$ ), $\mathrm{Na}, \mathrm{Mg}, \mathrm{Ca}, \mathrm{K}$ and $\mathrm{Cl}$ from ash or activated seaweed charcoal, shellfish, and husks. The high content of $\mathrm{Cl}$ will give the effect of namesake ion which will accelerate the deposition in the form of salt crystals. After knowing that the ADIRAMA additive formulation has a faster rate of salt flower formation than non-additives or RAMSOL additives, the study continued in application 2 .

The ADIRAMA additive application in stage 2 aims to find out the suitable ADIRAMA additive formulation, which can give a real effect on the salt produced both in terms of quality and speed of increase and the formation of salt flowers. The second application of Madura salt additives is different from the first application. In this second application, the land used is 6 plots and uses demonstration plots. The use of this demonstration plot aims to protect the process of making salt from bad weather (rain) so that the results are expected to be better. Besides that, demonstration plots used using flooring from tarpaulin materials, the use of tarps as a base for crystallization tables aims to prevent the influence of soil types on the salt produced so that the data obtained is expected to be more accurate. The treatments applied to this application include the addition of ADIRAMA additives with various compositions and concentrations (there are 5 different compositions and additives of ADIRAMA additives), and without additive additions. In this second application the steps taken are the same as the 1st application which consists of land preparation, mixing additives on the crystallization table, monitoring the progress of salt development in each plot and harvesting salt.

The salt application for stage II application tested in the Laboratory. Based on the results of the laboratory tests, it known that plot 6 (without the addition of additives) has the lowest $\mathrm{NaCl}$ level and the water content is quite high compared to the other 5 plots (with the addition of ADIRAMA additives). This condition, because in plot 1 until plot 5 is given treatment with the addition of ADIRAMA additives. The constituent constituents are activated charcoal seaweed, shells, rocks and rice husks, where the constituent elements of the additive consist of activated carbon, according to Siregar (2002) activated charcoal is an adsorbent which functions to clean salt from dangerous heavy 


\section{ADIRAMA: Production and Use of The Salt Additive of Madura}

metals. Calcium bicarbonate is the most common form of calcium compound dissolved in water; other calcium compounds have similar reaction equations. Every calcium carbonate produced will precipitate from the solution.

In addition, based on the results of the laboratory tests, it was found that the treatment in plot 3 (additive ADIRAMA formula 3) was the ideal formulation to be applied further. That indicated by the relatively high $\mathrm{NaCl}$ level, low water content and water-insoluble substances (impurities) are also relatively low. Although the composition is still inferior to the treatment in plot 1 , visually the appearance of salt produced from plot 3 has better visual quality (color and size) than in other plots. It can be said that the ADIRAMA 3 formulation is ideal for further testing.

The purpose and objective of the application of ADIRAMA additives stage 3 are to determine the effect of adding ADIRAMA 3 formula to the quality of salt in conditions in the demonstration plot with treatment without tarps (soil), with tarps and with the treatment system Madurese (plug). Furthermore, this application treatment 3 found the best treatment conditions for the addition of ADIRAMA 3 additive formulations.

In addition, in this application there are two treatments besides additives which are also differentiated as the base of the crystallization table, for this application two base methods are used, namely, without tarpaulin (soil) and by using tarps, this treatment aims to determine the effect of soil on salt yield. In addition, in the 3rd application, the additives are deposited first, then this is to prevent the remaining additives from being added to the crystallization table so that the salt yield is expected to be cleaner. In the third application, 6 plots of land were used and used demonstration plots. The use of this demonstration plot aims to protect the process of making salt from bad weather (rain) so that the results are expected to be better. In the third application, the stages carried out are the same as the first and second applications which consist of land preparation, mixing additives on the crystallization table, monitoring the progress of salt development in each plot and harvesting of salt.

Based on the table above, it known that in the treatment with the addition of ADIRAMA 3 additives, the $\mathrm{NaCl}$ content is higher when compared to without additives, this is closely related to the content of ADIRAMA 3 additives derived from activated charcoal, seaweed, rice husk, and shells. While the highest $\mathrm{NaCl}$ content is in the treatment with the addition of ADIRAMA 3 additives with tarpaulin, high chlorine content will give an ion effect which will accelerate precipitation in the form of salt crystals. In other hands, the treatment with ADIRAMA 3 additives also supported by the speed of increase in $\mathrm{Be}$ and the rate of formation of salt flowers more than without additive additions.

The ADIRAMA 3 treatment also indicates that the use of tarps on the surface of the land during the rainy season is essential because the salt formation process is not too affected by soil conditions. The soil condition at the time of this study was thought to have an important influence because the influence of rain affected the condition of the land. It is consistent with the opinion of Sidik et al. (2015) and Dradjid (2007) that; The nature of soil porosity affects the speed of seepage (leakage) of seawater into the soil that is being minimized or at the salt table. If the permeation rate is greater than the speed of evaporation, especially if there is rain during the manufacture of 
salt, the salt will not be produced. The type of soil also affects the color and impurity carried by the salt produced.

The high water content in each treatment with ADIRAMA additives, especially those on the ground due to application 3 is carried out in the rainy season, on high rainfall, so that water from outside the demonstration plot seeps into the plot of land. The influence of other rain is to slow down the salt formation process and influence the quality of salt. The chemical composition of salt produced under high rainfall conditions is generally relatively high, and the $\mathrm{NaCl}$ content is low. The treatment of tarp used for salt production in the good rainy season can be accepted rationally because salt with tarpaulin additives has the lowest water content and the highest $\mathrm{NaCl}$ content.

In this study, this condition found in the treatment with ADIRAMA 3 additives. The future agenda for increasing salt production to be more optimal, in addition to the use of additives to accelerate the production process, also requires another technological engineering, especially to deal with relatively short production periods due to more extended periods of the rainy season. These engineering technologies include; use of the backyard method and the use of tarps. One of the most current tarpaulin technologies is the use of geomembrane tarps.

The quality of salt, when viewed from the content of $\mathrm{NaCl}$ and its impuritis, can be seen in Table 1 .

Table 1. The content of $\mathrm{NaCl}$ and impurity are various types of salt

\begin{tabular}{|c|c|c|c|c|c|c|c|c|}
\hline & $\mathrm{NaCl}$ & $\mathrm{CaSO}_{4}$ & $\mathrm{CrCl}_{3}$ & $\mathrm{FeCl}_{3}$ & $\mathrm{CuCl}_{3}$ & $\mathbf{Z n S}$ & $\mathrm{CdS}$ & HgI \\
\hline Non Additive & $\%$ & $\%$ & $\%$ & $\%$ & $\%$ & $\%$ & $\%$ & $\%$ \\
\hline Ceramic & 93,94 & 1,9 & 0,09 & 0,12 & 0,024 & 0,009 & $\mathrm{TD}$ & $\mathrm{TD}$ \\
\hline LDPE & 92,65 & 5,8 & 0,10 & 0,12 & 0,024 & 0,01 & $\mathrm{TD}$ & TD \\
\hline Soil & 87,78 & 3,9 & 0,18 & 0,18 & 0,032 & 0,02 & $\mathrm{TD}$ & $\mathrm{TD}$ \\
\hline Additive & $\%$ & $\%$ & $\%$ & $\%$ & $\%$ & $\%$ & $\%$ & $\%$ \\
\hline Ceramic & 96,02 & 1,7 & 0,10 & 0,14 & 0,025 & 0,01 & $\mathrm{TD}$ & $\mathrm{TD}$ \\
\hline LDPE & 95,72 & 2,6 & 0,10 & 0,13 & 0,028 & 0,01 & $\mathrm{TD}$ & $\mathrm{TD}$ \\
\hline Soil & 93,81 & 2,3 & 0,09 & 0,14 & 0,026 & 0,01 & TD & TD \\
\hline
\end{tabular}

Information:

$\mathrm{TD}=$ no data because the compound concentration is less than $1 \mathrm{ppm}$

$\mathrm{Cl}=$ measured by argentometry titration $(\mathrm{SNI})$

Other impurities by means of XRF (Na and Mg do not appear in XRF analysis because the atomic mass is too light)

Based on the data in table 1, it known that overall the highest $\mathrm{Cl}$ content found in additive salt results, this result shows that salt with the addition of ADIRAMA additives has the highest $\mathrm{Cl}$ content, in other words, it also shows little impurities present in salt. Addition of additives, namely banana stem charcoal, rice husk charcoal and also limestone is intended to absorb impurities. The function of each type of additive is the same, namely as an absorbent because it has an active charcoal content even though the amount is different for each type.

The quantity of salt can be seen from the amount or weight of salt produced. The weight of salt produced from various types of treatment can be seen in Table 2 . Table 2. Quantity (weight) of various types of salt in the ADIRAMA 2017 demonstration plot development application 


\begin{tabular}{lc}
\hline \multicolumn{1}{c}{ Treatment } & Weight $(\mathrm{kg})$ \\
\hline Ceramics, Non-additive & 46,75 \\
LDPE, Non-additive & 50,75 \\
Soil, Non-additive & $\mathbf{2 6 , 9 5}$ \\
Ceramics, Additive & 47,65 \\
LDPE, Additive & 49,15 \\
Soil, Additive & 32,50 \\
\hline
\end{tabular}

The data in table 2, shows a significant difference between the weight of non-additive salt and additive salt, the amount of salt with the addition of ADIRAMA additives tends to be heavier than non-additive salts. These results are related to the function of additives added to seawater as a raw material in the process of making salt. The ingredients of ADIRAMA additives contain the same elements, namely activated charcoal (activated carbon). Given the function of activated carbon as a binder or absorbent of unwanted substances including impurities, so the content of the additive salt produced is relatively purer when compared to non-additive salts. Besides, the function of activated carbon that can absorb water from the material will tend to increase the density (elements contained in salt water). It will affect the amount of salt produced, meaning the more concentrated content of the saltforming, the salt produced tends to be more than with salt water that is less concentrated in this case is called Boume.

Siregar (2002) said that activated charcoal has unique characteristics that can be used in many ways. Like having small cavities that are very much in the direction so that 1 gram of charcoal has a surface area of about $250 \mathrm{~m}^{2}$. These cavities can attach different substances to the wall, which are later released. Some examples of the use of charcoal are absorbing water from moist air, then releasing it in dry conditions. That makes it a good humidity regulator. In addition, charcoal also has the benefit of absorbing unpleasant odors and harmful substances.
The data in Table 2 also shows that in addition to the weight of the additive salt which is higher than the non-additive. It seen that the highest salt weight is salt with non-additive treatment and with the use of LDPE base, this is due to the influence of high impurity one of which is $\mathrm{Ca}$, where This amount of impurity is the highest compared to salt with other treatments. The impurities in the base of LDPE will accumulate and not be caught by any element (additives). In addition, there is no seepage of salt water into the soil because everything is contained in LDPE. Whereas, the weight of salt with a foundation of land (although the base of the land with higher additives compared to the base of non-additive soil) is the lowest compared to salt using LDPE and ceramic bases. It is related to the nature of the soil which has high porosity so that saltwater seeps into the soil and not entirely formed into salt crystals.

\section{Conclusion}

In the process of using salt additives is an idea that arises because naturally, the people of Madura have used it, namely adding trusi in terms of facing the process of water that has impurities and materials. The sea water that experiences the process of adding additives has the highest $\mathrm{NaCl}$, ceramics land 96.02\%, LDPE land $95.72 \%$ and land area $93.81 \%$. And for some treatments for several treatments heavier than others, namely ceramics with additives of $47.65 \mathrm{Kg}$, LDPE with additives $49.15 \mathrm{Kg}$, and soil with additives $32.50 \mathrm{Kg}$.

\section{References}

Dradjid. (2007). Teknik Pembuatan Garam. BPPP. Banyuwangi.

Efendy M, Heriyanto, Sidik RF.(2011) Garam Madura. Prospek dan 
Sidik and Efendy

Tantangannya. UTM Press.

Bangkalan.

Siregar, C.A. dan Siringoringo, H.H. (2002). Pengaruh Aplikasi Arang Terhadap Pertumbuhan Awal

Michelia Montana Blume Dan Perubahan Sifat Kesuburan Tanah Pada Tipe Tanah Latosol. Pusat Litbang Konservasi dan Rehabilitasi. Bogor.

Sidik RF, Syafii M, Effendy M. (2015).

Pengurangan nilai porositas dalam pengolahan peminian garam. Pamekasan.. Wacana Didaktika. Vol. 3. No 1 